Check for updates

Cite this: RSC Adv., 2018, 8, 5828

Received 11th September 2017

Accepted 28th January 2018

DOI: 10.1039/c7ra10097c

rsc.li/rsc-advances

\section{Conversion mechanism of heptachlor by a novel bacterial strain}

\author{
Liping Qiu, (D) $\dagger^{\star a}$ Hu Wang $\dagger^{\mathrm{b}}$ and Xuntao Wang $\dagger^{\mathrm{b}}$
}

Microbial treatment is the preferred method for the remediation of soil and water contaminated by heptachlor. We collected sludge samples from the sewage biological treatment pool of Shaanxi Insecticide Factory in Xi'an, China, which were used as bacteria source. With heptachlor as the substrate, at $30-35{ }^{\circ} \mathrm{C}$, an effective microorganism (named strain $\mathrm{H}$ ) for heptachlor degradation was isolated successfully after a long period of acclimation, screening and purification. Strain $\mathrm{H}$ was able to use heptachlor as a carbon source and had a good capacity for biodegradation of heptachlor. Strain $\mathrm{H}$ was preliminarily identified as a Gram-negative, short rod-shaped, single-cell bacterial strain that was similar to the genus Escherichia or Shigella, according to the analysis of its morphology and physiologicalbiochemical characteristics. Then, strain $\mathrm{H}$ was further identified as a novel bacterium based on the similarity analysis of its $16 \mathrm{~S}$ rDNA gene sequence with the sequences logged in the RDP and GenBank databases. The $16 \mathrm{~S}$ rDNA of this bacterium has never been reported before. When the inoculation volume and the $\mathrm{pH}$ were $20 \%$ and $7.1-7.6$, respectively, the degradation rate of heptachlor can reach more than $88.2 \%$ in $130 \mathrm{~h}$, with the initial concentration of heptachlor being $300 \mu \mathrm{g} \mathrm{L}^{-1}$ at $30-35{ }^{\circ} \mathrm{C}$. Identification of the metabolites by GC/MS showed that strain $\mathrm{H}$ degrades heptachlor via two pathways simultaneously, i.e., pathway (1) hydroxylation at the C1 position of heptachlor to 1-hydroxychlordene followed by epoxidation and dechlorination to chlordene epoxide; and pathway (2) epoxidation at the C2 and $\mathrm{C} 3$ positions of heptachlor to heptachlor epoxide, and then heptachlor epoxide was further transformed to chlordene epoxide by dechlorination reaction, or degraded to heptachlor diol by hydrolysis reaction. The biodegradation of heptachlor indicated that heptachlor and its metabolites can be converted into less-toxic small molecular metabolites by a series of reactions such as epoxidation, hydrolysis and dechlorination reactions.

\section{Introduction}

Heptachlor $\left(\mathrm{C}_{10} \mathrm{H}_{5} \mathrm{Cl}_{7}\right)$ is an organochlorine cyclodiene insecticide, first isolated from technical chlordane in 1946. During the 1960 s and 1970s, it was used primarily by farmers to kill termites, ants, and soil insects in seed grains and on crops, as well as by exterminators and home owners to kill termites. Heptachlor is a highly to moderately toxic compound in EPA toxicity class II. In 1988, the EPA canceled all uses of heptachlor in the U.S. The only commercial use still permitted is for fire ant control in power transformers. ${ }^{1}$ Heptachlor is still available outside the U.S. ${ }^{2}$ For example, some developing countries continue to use this pesticide in both agriculture and public health programs because of its low cost and versatility in

${ }^{a}$ Key Laboratory of Subsurface Hydrology and Ecological Effects in Arid Regio, Ministry of Education, School of Environmental Science and Engineering, Chang'an University, Xi'an, 710054, P. R. China. E-mail: lpqiu3699@sina.com; Fax: +86-29-80334563; Tel: +81-29-80334563

${ }^{b}$ School of Natural and Applied Sciences, Chang'an University, Xi'an, 710064, P. R. China

$\dagger$ Authors contributed equally. controlling various pests. ${ }^{3}$ Before heptachlor was banned, formulations available included dusts, wettable powders, emulsifiable concentrates, and oil solutions. It acts as a nonsystemic stomach and contact insecticide. ${ }^{4}$

The use of microbial degradation is one of the most effective ways to remove pollutants in the environment because it enjoys less chemical agents, lower energy consumption, lower cost, milder reaction condition and less secondary pollution compared to physicochemical methods for heptachlor treatment. Microbiological treatment technology of organochlorine pesticides pollution has become an important research direction. At present, the study of heptachlor concentrates on the distribution characteristics and toxic effects in the environment, while few studies have been conducted on microbial degradation. ${ }^{5-7}$ We isolated a novel bacterial strain that can grow using heptachlor as the carbon source and has high degradation efficiency from the sludge of sewage biological treatment pool in chemical plant. Subsequently, we carried out the identification of physiological and biochemical characteristics for the isolate, and the identification of its 16S rDNA gene sequence. The 
metabolites of heptachlor were analyzed through GC/MS, and search matching with the NIST spectral library, as well as comparison with standard compounds. On this basis, we studied the bioconversion mechanisms and degradation pathways of heptachlor. This study is expected to provide a good microbiological source, as well as theoretical basis for biodegradation of soil and water contaminated by heptachlor in the future.

\section{Materials and methods}

\section{Materials}

The mineral salt medium (MSM) contained $\left(\mathrm{g} \mathrm{L}^{-1}\right): 0.5 \mathrm{~g}$ $\mathrm{NH}_{4} \mathrm{NO}_{3}, 1.5 \mathrm{~K}_{2} \mathrm{HPO}_{4} \cdot 3 \mathrm{H}_{2} \mathrm{O}, 1.0 \quad \mathrm{MgSO}_{4} \cdot 7 \mathrm{H}_{2} \mathrm{O}, 0.03 \mathrm{FeSO}_{4}^{-}$ $\cdot 7 \mathrm{H}_{2} \mathrm{O}, 1.0 \mathrm{NaCl}$ and $2 \mathrm{~mL}$ of trace elements solution which contained ( $\left.\mathrm{g} \mathrm{L}^{-1}\right): 0.2 \quad \mathrm{ZnSO}_{4} \cdot 7 \mathrm{H}_{2} \mathrm{O}, 2.0 \quad \mathrm{CaCl}_{2} \cdot 2 \mathrm{H}_{2} \mathrm{O}, 0.2$ $\mathrm{MnSO}_{4} \cdot 4 \mathrm{H}_{2} \mathrm{O}, 0.1 \mathrm{CuSO}_{4} \cdot 2 \mathrm{H}_{2} \mathrm{O}, 0.12 \mathrm{CoCl}_{2} \cdot 6 \mathrm{H}_{2} \mathrm{O}, 0.12 \mathrm{Na}_{2}-$ $\mathrm{MoO}_{4} \cdot 2 \mathrm{H}_{2} \mathrm{O}$ and $0.10 \mathrm{H}_{3} \mathrm{BO}_{3}$. Luria-Bertani (LB) liquid medium contained the following ingredients $\left(\mathrm{g} \mathrm{L}^{-1}\right)$ : 10.0 peptone, 5.0 sodium chloride, 10.0 yeast extract.

Heptachlor standard (1 mg mL $\mathrm{mL}^{-1}$ in methanol) and heptachlor epoxide standard ( $1 \mathrm{mg} \mathrm{mL} \mathrm{m}^{-1}$ in methanol) were obtained from Aladdin Industrial Corporation (Shanghai, China). 1Hydroxychlordene standard (10 $\mathrm{g} \mathrm{mL}^{-1}$ in cyclohexane) was obtained from Dr Ehrenstorfer $\mathrm{GmbH}$, Germany. $\mathrm{N}$-Hexane (chromatographically pure solvents) was obtained from American TEDIA Company.

All other chemical reagents used in the experiments were of analytical reagent grade.

\section{Isolation of the heptachlor-degrading bacterium}

Sludge samples were taken from the sludge of sewage biological treatment pool of Shaanxi Insecticide Factory in Xi'an, China in April 2016. The basic operating parameters of sewage biological treatment are as follows: $200 \mathrm{~m}^{3} \mathrm{~h}^{-1}$ of influent water, $1.23 \mathrm{~kg}$ [CODcr] per $\left(\mathrm{m}^{3} \mathrm{~d}\right)$ of volume load, $25-30{ }^{\circ} \mathrm{C}$ of operating temperature, $\mathrm{A}^{2} / \mathrm{O}$ systems. Sludge volume index (SVI) 130$150 \mathrm{~mL} \mathrm{~g}^{-1}$. The initial enrichment culture was established in a $250 \mathrm{~mL}$ Erlenmeyer flask by inoculating $200 \mathrm{~mL}$ sterile MSM containing $100 \mu \mathrm{g} \mathrm{L}^{-1}$ heptachlor with $10 \mathrm{~g}$ sludge samples (wet weight). The Erlenmeyer flask was incubated on a constanttemperature rotary shaking incubator (BS-1E, China) at $30{ }^{\circ} \mathrm{C}$ and $120 \mathrm{rpm}$. After one-week's incubation, portions were inoculated into a fresh sterile MSM with heptachlor concentration up to $300 \mu \mathrm{g} \mathrm{L}^{-1}$, and incubation was continued. After five more transfers at 1 week intervals, the culture was purified by the plate separation method onto solidified MSM containing $300 \mu \mathrm{g}$ $\mathrm{L}^{-1}$ heptachlor. Finally, a pure strain was isolated and named as strain $\mathrm{H}$.

\section{Identification of strain $\mathbf{H}$}

A MOTIC digital biological microscope (DMBA400-P, China) and a scanning electron microscope (S-4800, Hitachi) were used for the observation of the morphology and the size of the bacterium. Physiological and biochemical characteristic of strain $\mathrm{H}$ were determined by the procedures described from
Bergey's Manual of Determinative Bacteriology ${ }^{8}$ and Manual of Common Bacterial System Identification. ${ }^{9}$

The DNA of the strain $\mathrm{H}$ culture was obtained using a commercial genomic DNA extraction kit (SK1201-UNIQ-10, Shanghai Sangon Biotech Co., Ltd., China). 16S rRNA gene of the strain was amplified from the bacterial genomic DNA by a PCR using universal primers of $7 \mathrm{~F}$ (5'-CAGAGTTTGATCCTGGCT-3') and R1540 (5'-AGGAGGTGATCCAGCCGCA$\left.3^{\prime}\right) .{ }^{10}$ PCR amplification condition was as follows: each PCR mixture $(25 \mu \mathrm{L})$ was composed of $0.5 \mu \mathrm{L}$ genomic DNA ((20-50 ng $\mu \mathrm{L}^{-1}$ )); $1.0 \mu \mathrm{L}$ of dNTP at $2.5 \mathrm{mM} ; 2.5 \mu \mathrm{L} 5 \times$ buffer (with $\left.20 \mathrm{mmol} \mathrm{L}{ }^{-1} \mathrm{Mg}^{2+}\right) ; 0.5 \mu \mathrm{L}$ forward primer $\left(10 \mu \mathrm{mol} \mathrm{L}^{-1}\right), 0.5 \mu \mathrm{L}$ reverse primer $\left(10 \mu \mathrm{mol} \mathrm{L}{ }^{-1}\right), 0.2 \mu \mathrm{L}$ Taq $\left(5 \mathrm{U}^{-1}\right)$, and sterile water. The PCR was performed in a PTC-100 Peltier Thermal Cycler (MJ Research, USA) with a hot starting performed at $98{ }^{\circ} \mathrm{C}$ for $5 \mathrm{~min}$, followed by 28 cycles of $98{ }^{\circ} \mathrm{C}$ for $30 \mathrm{~s}$, annealing at $55{ }^{\circ} \mathrm{C}$ for $45 \mathrm{~s}$, and $72{ }^{\circ} \mathrm{C}$ for $1 \mathrm{~min}$, followed by a final extension at $72{ }^{\circ} \mathrm{C}$ for $10 \mathrm{~min}$.

The 16S rRNA gene of about $1.5 \mathrm{~kb}$ was purified using a gel extraction kit (SK1191-UNIQ-10, Shanghai Sangon Biotech Co., Ltd., China), and the purified product was ligated with pMD 18$\mathrm{T}$ vector. Then the ligation product was transformed into competent bacterial strain JM109, and the positive clones were picked out according to blue/white screening. The recombinant plasmid was extracted from the positive clone according to alkaline lysis method. ${ }^{11}$

The PCR products were purified and sequenced at Shanghai Sangon Biotech Co., Ltd., (China) and compared with 16S rDNA sequence data from type strains available in Genbank (http:// www.ncbi.nlm.nih.gov) and the Ribosomal Database Project [RDP] (http://rdp.cme.msu.edu/index.jsp) using the BLASTN and RDP sequence match routines. The sequences were aligned using multiple sequence alignment software CLUSTAL W version 1.81. A phylogenetic tree was then constructed by the neighbor-joining method using the MEGA software (version 4.1) based on the 16S rDNA sequences.

\section{Growth curve of strain $\mathbf{H}$}

We incubated the isolated strain $\mathrm{H}$ in a sterilized LB (initial concentration of the strain: $1.2 \times 10^{8}$ cells per $\mathrm{mL}$ ) in a shaking incubator at $30 \pm 0.5^{\circ} \mathrm{C}$ and $120 \mathrm{rpm}$ to obtain the growth curve of strain $\mathrm{H}$ at different phases by measuring the concentration of strain $\mathrm{H}$ periodically.

\section{Optimal conditions of heptachlor degradation by strain $\mathbf{H}$}

Strain $\mathrm{H}$ at the logarithmic growth phase was collected by centrifugation. The strain was then resuspended using physiological saline water. The resulting suspension was used as degradation inoculation solution for all the following experiments. Effects of environmental conditions for the growth of strain $\mathrm{H}$ and heptachlor degradation were investigated. In each of our experiments, a $250 \mathrm{~mL}$ Erlenmeyer flask was used which contains $200 \mathrm{~mL}$ sterilized MSM containing $300 \mu \mathrm{g} \mathrm{L}^{-1}$ heptachlor and $20 \%$ of inoculation volume with a biomass content of $1.2 \times 10^{8}$ cells per $\mathrm{mL}$, and the degradation time was $140 \mathrm{~h}$. Tests on the effect of temperature were first examined at five 
levels, $20,25,30,35$ and $40{ }^{\circ} \mathrm{C}$. The temperature is automatically set and adjusted by the constant-temperature rotary shaking incubator (BS-1E, China), at $\mathrm{pH}$ 7. These were followed by tests on the effect of $\mathrm{pH}$ at six levels from $\mathrm{pH} 5.2$ to 9.3. The $\mathrm{pH}$ level is adjusted with $10 \% \mathrm{NaOH}$ solution and $10 \% \mathrm{HCl}$ solution. The $\mathrm{pH}$ level is measured by the $\mathrm{pH}$ meter (FE20K, METTLER TOLEDO, Switzerland) at the identified optimal temperature. Experiments on heptachlor degradation were carried at the optimal $\mathrm{pH}$ and temperature in $250 \mathrm{~mL}$ Erlenmeyer flasks at $120 \mathrm{rpm}$. Each flask contained $20 \%$ of inoculation volume (1.2 $\times 10^{8}$ cells per $\mathrm{mL}$ ) and $200 \mathrm{~mL}$ MSM with heptachlor initial concentration varying from 100 to $500 \mu \mathrm{g} \mathrm{L}^{-1}$.

\section{Metabolites and conversion mechanism of heptachlor}

Heptachlor degradation and strain $\mathrm{H}$ growth were examined at the identified optimal conditions. The metabolites of heptachlor were qualitatively and quantitatively analyzed by gas chromatography-mass spectrometry (GC/MS2010, Shimadzu Corp.), and comparison with standard compounds and document data. Subsequently, the degradation mechanism of heptachlor by strain $\mathrm{H}$ was investigated.

\section{Concentration determination of heptachlor, its metabolites and strain cells}

The concentrations of heptachlor and its metabolites were analyzed by a Shimadzu GC/MS2010 apparatus with a RTX-5MS from Shimadzu $(30 \mathrm{~m} \times 0.25 \mathrm{~mm} \times 0.25 \mathrm{~mm})$. The column temperature program was $80{ }^{\circ} \mathrm{C}$ isothermal for $5 \mathrm{~min}$ and then from $80{ }^{\circ} \mathrm{C}$ to $260{ }^{\circ} \mathrm{C}$ with an increment of $10^{\circ} \mathrm{C} \mathrm{min}^{-1}$. The MS energy was derived from a $70 \mathrm{eV}$ electron ionization source of electron bombardment; ion source temperature was maintained at $200{ }^{\circ} \mathrm{C}$; interface temperature was maintained at $260{ }^{\circ} \mathrm{C}$; mass scan range was set at $40-450 \mathrm{~m} / \mathrm{z}$.

Samples were prepared in a $40 \mathrm{~mL}$ brown reagent bottle. A volume of $10 \mathrm{~mL}$ sample contained heptachlor and its metabolites obtained after the pretreatment of the bacterial cultures was placed into the reagent bottle, and then five milliliter $n$-hexane was added. ${ }^{12,13}$ The bottle was kept in a constant-temperature rotating shaker (HZQ-C, China) at $200 \mathrm{rpm}$ for $20 \mathrm{~min}$ and then in ultrasonic waves at $28 \mathrm{kHz}$ frequency for $10 \mathrm{~min}$ for heptachlor extraction. The extraction process was repeated three times. The organic fraction was dried over anhydrous sodium sulfate. Finally, $1 \mu \mathrm{L}$ of the dry organic sample that passed through an organic filter (hydrophobic PTFE) of $0.22 \mu \mathrm{m}$ pore size was analyzed by GC/ MS.

The cell concentrations of all samples were detected using Visible Spectrophotometry and Petroff-Hausser counting chamber. $^{14}$

\section{Statistical analysis}

Excel 2007 and SPSS statistical software were used for data processing and statistical analysis of the experimental results. All the experiments were conducted in triplicate. The relative standard deviation of all the data points in this paper was between $0.72 \%$ and $4.63 \%$.

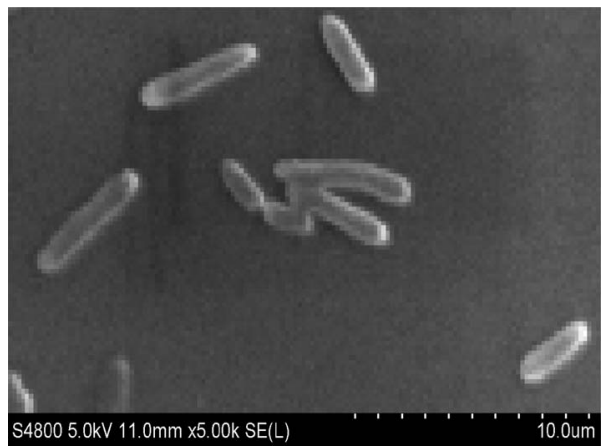

Fig. 1 Electronic microscopy photograph of strain $\mathrm{H}$.

\section{Results and discussion}

\section{Identification of strain $\mathbf{H}$}

Strain $\mathrm{H}$ was inoculated to a sterilized solidified MSM also containing $300 \mu \mathrm{g} \mathrm{L^{-1 }}$ heptachlor and incubated for $120 \mathrm{~h}$. Through the MOTIC digital biological microscope and a scanning electron microscope (S-4800, Hitachi), strain $\mathrm{H}$ was observed as a short rod-shaped, single-cell Gram-negative bacterium (Fig. 1). The colony morphology of strain H showed

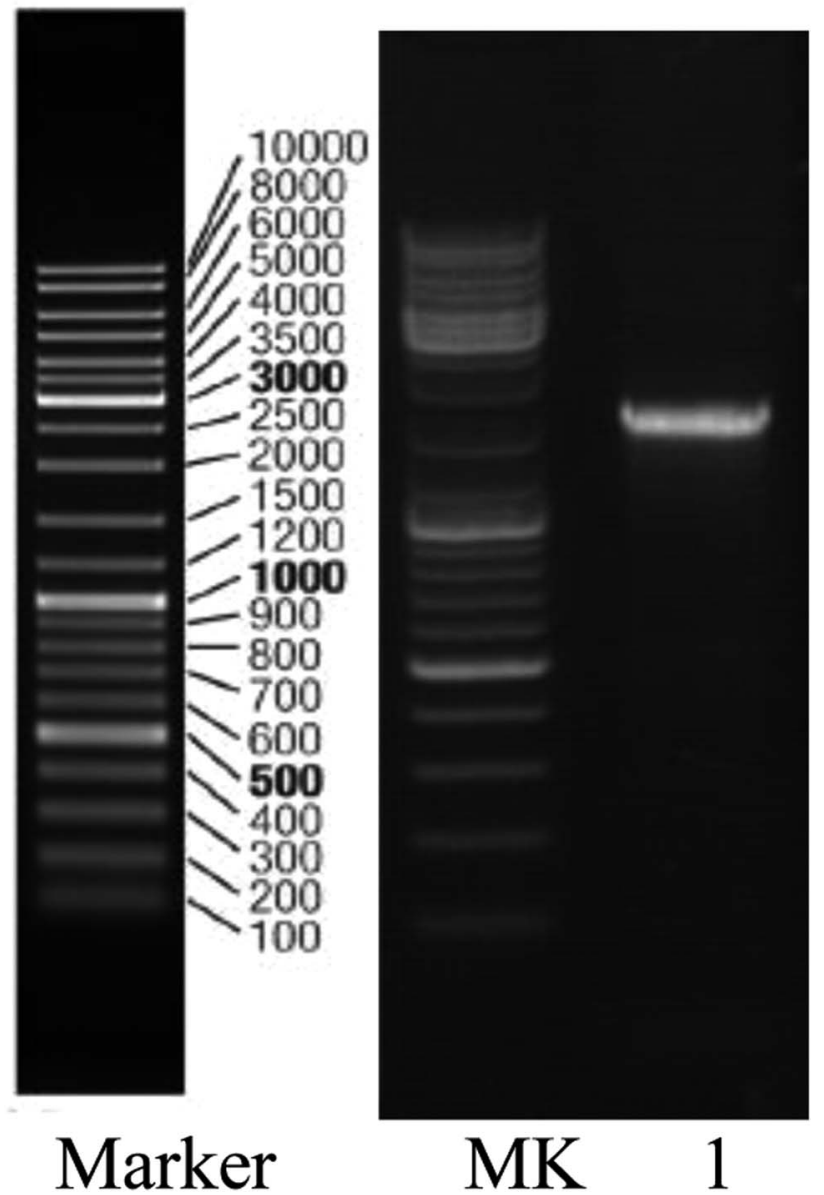

Fig. 2 Gel electrophoresis pattern of the PCR amplification product of strain H: lane 1, strain QL; MK, Marker (DL2000). 


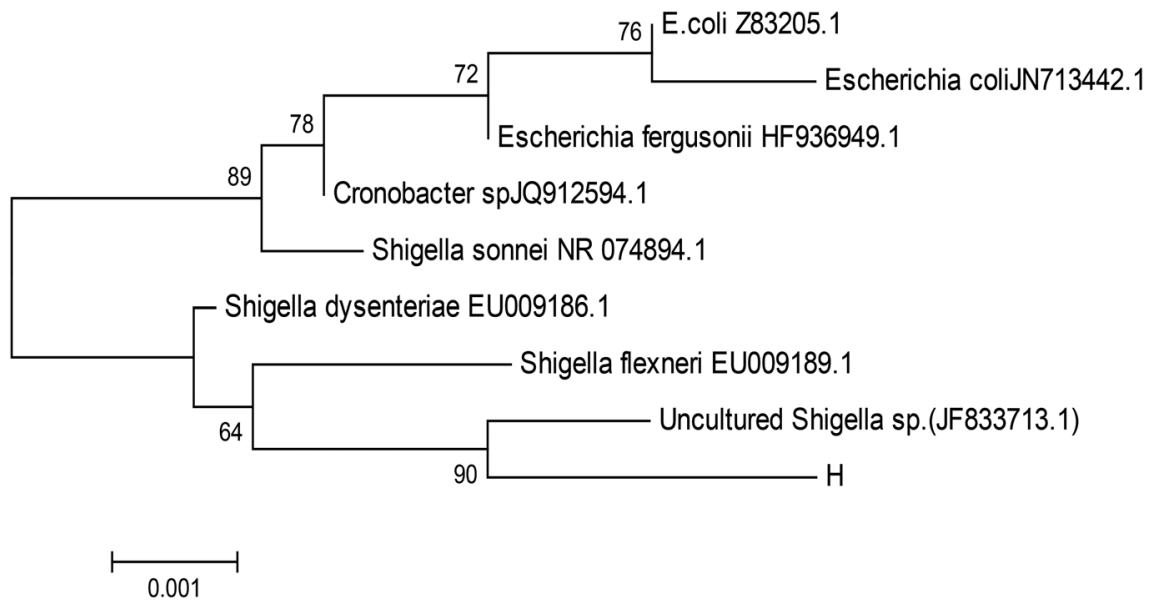

Fig. 3 Phylogenetic tree based on 16S rDNA sequences. Numbers at the nodes indicated the percentages of bootstrap samplings, derived from 1000 samples that support the internal branches.

pale yellow and circular. The diameter of the colony was less than $0.3 \mathrm{~cm}$, smooth on the surface and trim on the edge, and translucent. There was a slight bump in the middle. Methyl red reaction, starch hydrolysis and catalase reaction were positive. $\mathrm{V}-\mathrm{P}$ reaction, oxidase and gelatin reaction were negative. Phenotypic and physiochemical experiments suggested that strain $\mathrm{H}$ was similar to genus Escherichia or genus Shigella.

The bacterium was further identified by $16 \mathrm{~S}$ rDNA analysis. After gel electrophoresis of the PCR amplification product of strain $\mathrm{H}$ as shown in Fig. 2, a single band of 1.5 kilobases (kb) could be seen by comparing with the DNA Ladder Mix Marker (DL2000) in the gel imager. The accurate length of the band was determined as 1534 base pairs (bp) after sequencing. The $16 \mathrm{~S}$ rDNA gene sequence of strain $\mathrm{H}$ (accession number: BankIt2073018 Seq1 MG711918) was compared with the sequences logged in the RDP and GenBank databases. Strain $\mathrm{H}$ was further identified as a novel bacterium because its homology with all known strains was very small based on homology analysis. The phylogenetic tree of strain $\mathrm{H}$ was constructed based on 16S rDNA sequences (Fig. 3).

\section{Growth curve of the activity strain}

From the growth curve of strain $\mathrm{H}$ (Fig. 4), we can see that the lag phase lasted from 0 to $30 \mathrm{~h}$, the logarithmic phase lasted from 30 to $60 \mathrm{~h}$, the stationary phase lasted from 60 to $120 \mathrm{~h}$, and the death phase began at $120 \mathrm{~h}$.

\section{Optimal conditions of heptachlor degradation by strain $\mathbf{H}$}

The effect of temperature on the growth of strain $\mathrm{H}$ is shown in Fig. 5a and $\mathrm{b}$. The growth of strains would be affected under too high or too low temperature. $30{ }^{\circ} \mathrm{C}$ was suitable for the growth of strain $\mathrm{H}$. The degradation rate of heptachlor was poor under the condition of $20^{\circ} \mathrm{C}$ and $40^{\circ} \mathrm{C}$. The degradation of heptachlor was better when the temperature was between $25{ }^{\circ} \mathrm{C}$ and $35^{\circ} \mathrm{C}$. The degradation rate of heptachlor was the best at $30{ }^{\circ} \mathrm{C}$. The growth curves at different temperature are shown in Fig. 13.
The effect of initial $\mathrm{pH}$ value on the degradation of heptachlor is shown in Fig. 5c and 11. The cell concentration of strain $\mathrm{H}$ increased quickly when $\mathrm{pH}$ increased from 5.2 to 7.1. The highest cell concentration was observed at $\mathrm{pH}$ 7.1-7.6. When $\mathrm{pH}$ was above 7.6, the cell concentration decreased gently. Under the acidic condition $(\mathrm{pH}<6)$, the degradation rate of heptachlor by strain $\mathrm{H}$ was very low. Under the neutral and alkaline conditions, the degradation became high. When $\mathrm{pH}$ was 7.6, the degradation rate reached the maximum. We reason that the degrading activity of the enzyme ${ }^{15}$ produced by strain $\mathrm{H}$ was low under the acidic conditions, and the degrading activity was higher under neutral and alkaline conditions. When $\mathrm{pH}$ was 7.1-7.6, the degrading activity was the highest, so the degradation effect was the best. The growth curves at different pH levels are shown in Fig. 14.

Different heptachlor initial concentrations were assessed as shown in Fig. 5d and 12. It can be seen that strain $\mathrm{H}$ had strong degradation capacity of heptachlor, especially at low heptachlor concentration (99.6-202.3 $\mu \mathrm{g} \mathrm{L}^{-1}$ ). When the heptachlor initial

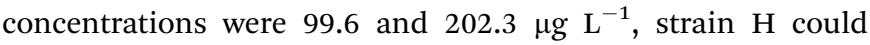
degrade heptachlor $86.3 \%$ and $86.8 \%$, respectively. No

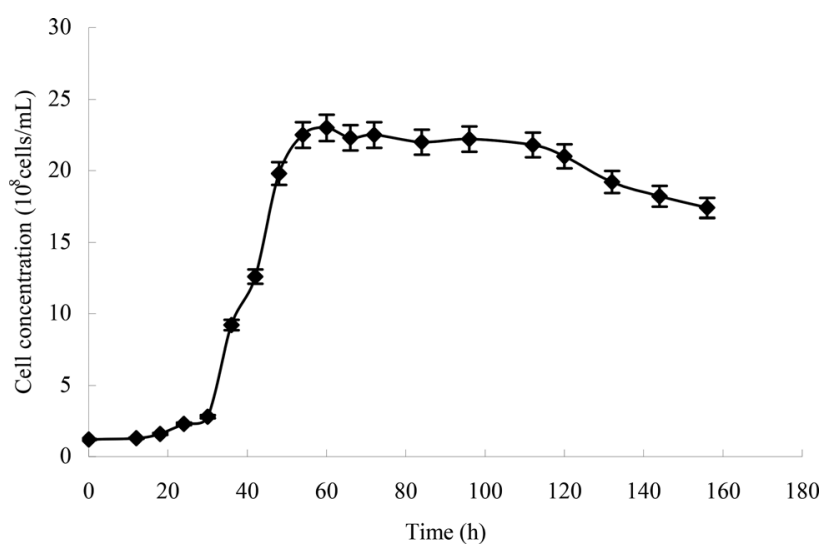

Fig. 4 Growth curve of the strain (initial concentration: $1.2 \times 10^{8}$ cells per $\mathrm{mL}$ ) in LB. 

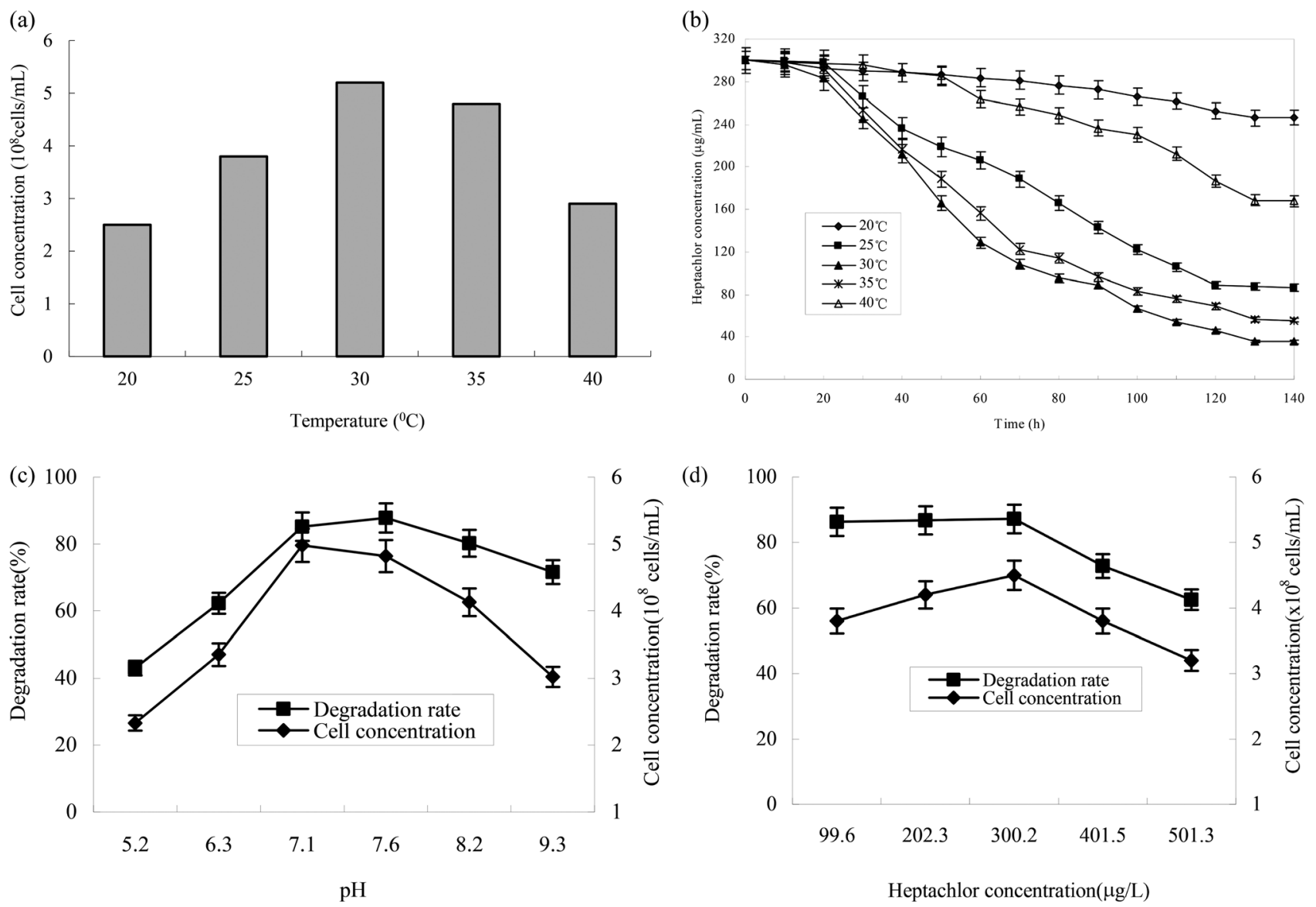

Fig. 5 Effects of different conditions on heptachlor degradation characterization by strain $\mathrm{H}$. (a) Effect of temperature on the growth of strain $\mathrm{H}$; (b) effect of temperature on heptachlor degradation by strain $\mathrm{H}$; (c) degradation $\mathrm{pH}$ values; (d) initial heptachlor concentrations.

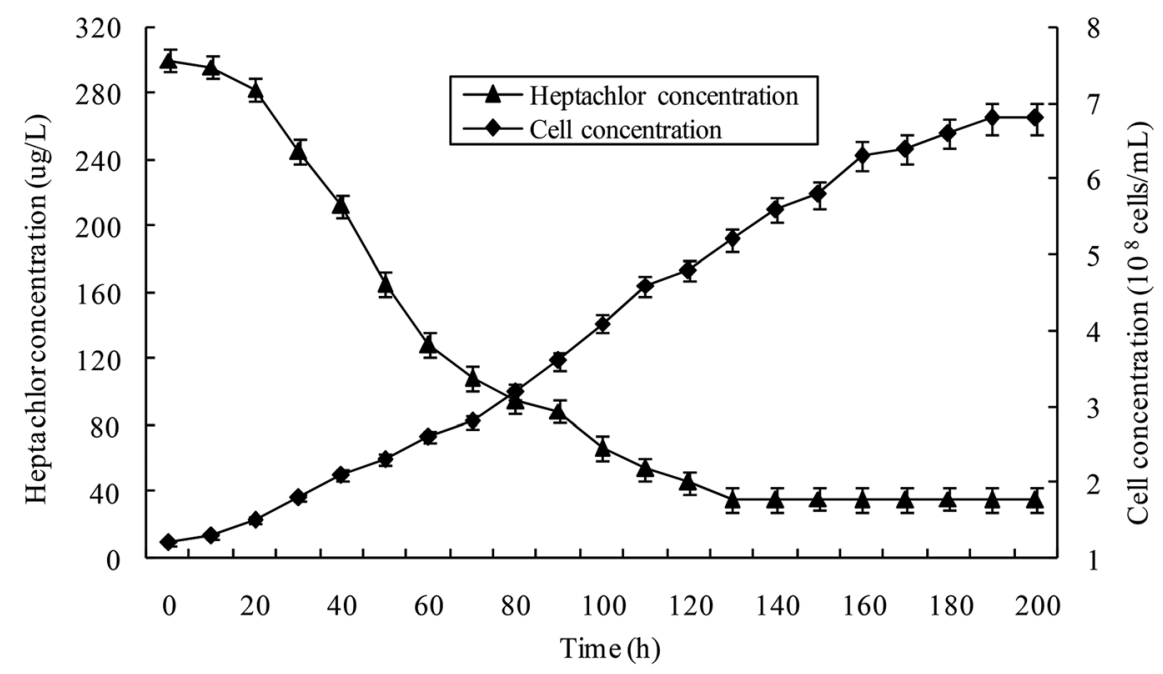

Fig. 6 Heptachlor degradation and the growth of strain $\mathrm{H}$ at the optimal conditions.

appreciable loss of heptachlor was observed in the sterile control. 99.6-202.3 $\mu \mathrm{g} \mathrm{\textrm {L } ^ { - 1 }}$ were heptachlor concentrations detected in most contaminated soil and discharged wastewater, ${ }^{16}$ so the strain has a great advantage of solving practical heptachlor pollution.
The degradation rate of heptachlor increased with increasing heptachlor concentration up to $300.2 \mu \mathrm{g} \mathrm{L}^{-1}$, the largest degradation rate attained $87.2 \%$. When the heptachlor

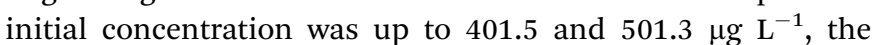
degradation rate were $75.6 \%$ and $62.5 \%$, respectively. This 


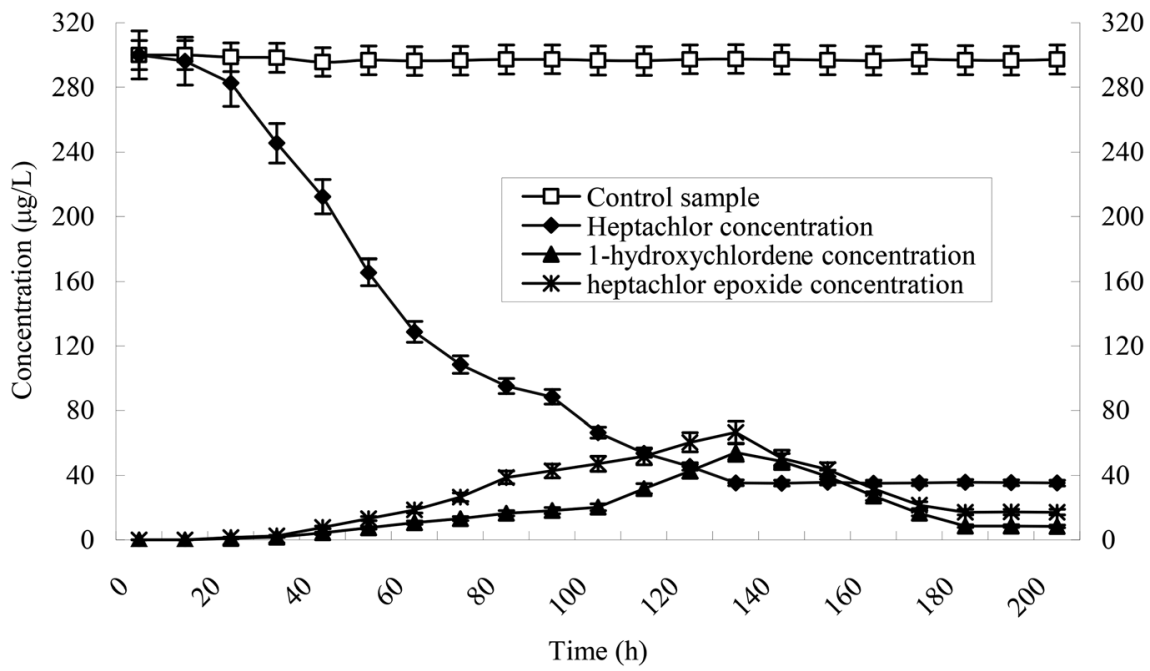

Fig. 7 Time course of degradation of heptachlor and production of some metabolites.

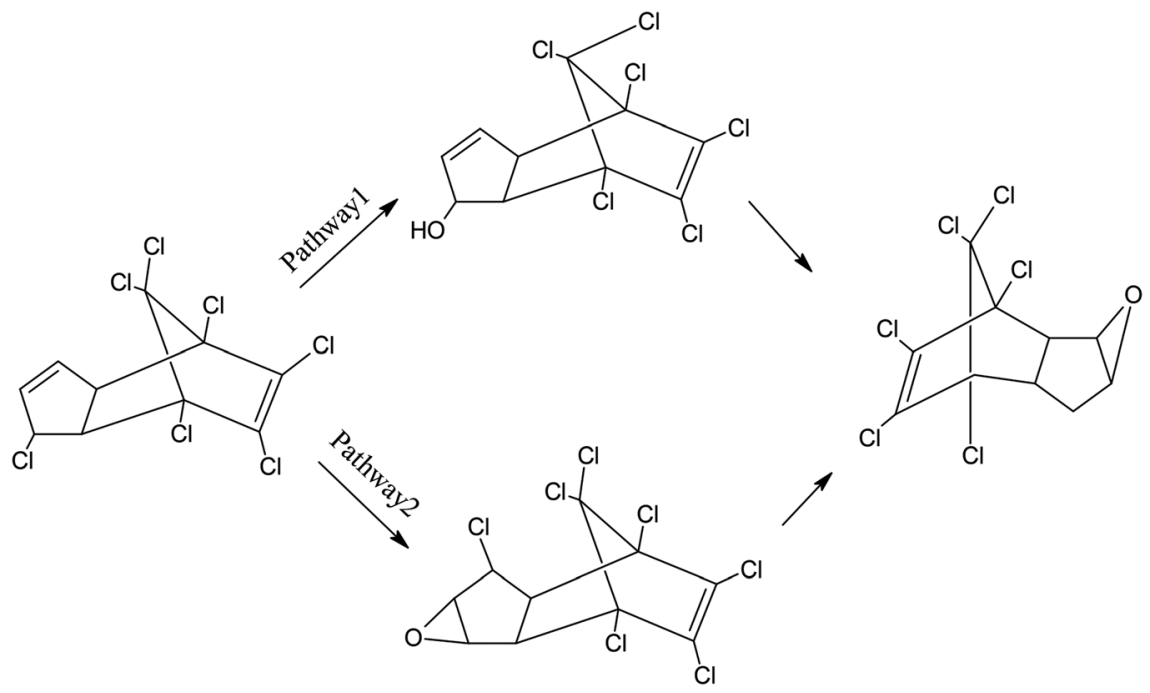

Fig. 8 The proposed metabolic pathways of heptachlor by strain $\mathrm{H}$.

result could be due to the toxicity of heptachlor to the microorganism. Once the heptachlor initial concentration exceeded a certain value, it would inhibit the growth of strain $\mathrm{H}$, thus inhibiting its degradation ability. ${ }^{17}$ The growth curves at different heptachlor concentrations are shown in Fig. 15.

\section{Metabolites and conversion mechanism of heptachlor}

Heptachlor biodegradation and the growth of strain $\mathrm{H}$ is shown in Fig. 6 under the above identified optimal conditions. The cell concentration of strain $\mathrm{H}$ increased as the concentration of heptachlor decreased at the optimal conditions. Even after the heptachlor degradation ability reached the maximum at $130 \mathrm{~h}$, the bacteria continued to grow, which indicates that strain $\mathrm{H}$ can grow on some of the degradation products of heptachlor such as 1-hydroxychlordene or heptachlor epoxide. Heptachlor epoxide has similar toxicity with heptachlor, and some studies have shown that certain microorganisms, such as Phlebia, can open the oxygen ring structure of heptachlor epoxide by hydrolysis reaction, and that heptachlor epoxide can be further converted into hydroxylated metabolites such as the relatively less-toxic 1-hydroxychlordene. 1-Hydroxychlordene could be metabolized easily into hydrophilic products of even less toxicity. ${ }^{18-20}$ From Fig. 7, we observe that the concentrations of the heptachlor metabolites gradually decreased over time: 1hydroxychlordene from $54.2 \mu \mathrm{g} \mathrm{L}^{-1}$ to $8.3 \mu \mathrm{g} \mathrm{L} \mathrm{L}^{-1}$, and heptachlor epoxide from $66.6 \mu \mathrm{g} \mathrm{L}^{-1}$ to $17.2 \mu \mathrm{g} \mathrm{L}^{-1}$, which verified the theory.

Metabolites and conversion mechanism of heptachlor is shown Fig. 7. During the degradation process, the degradation of heptachlor was accompanied by the production of metabolites. When the heptachlor degradation rate reached the maximum, $88.2 \%$ at $130 \mathrm{~h}, 3$ main metabolites were detected in 


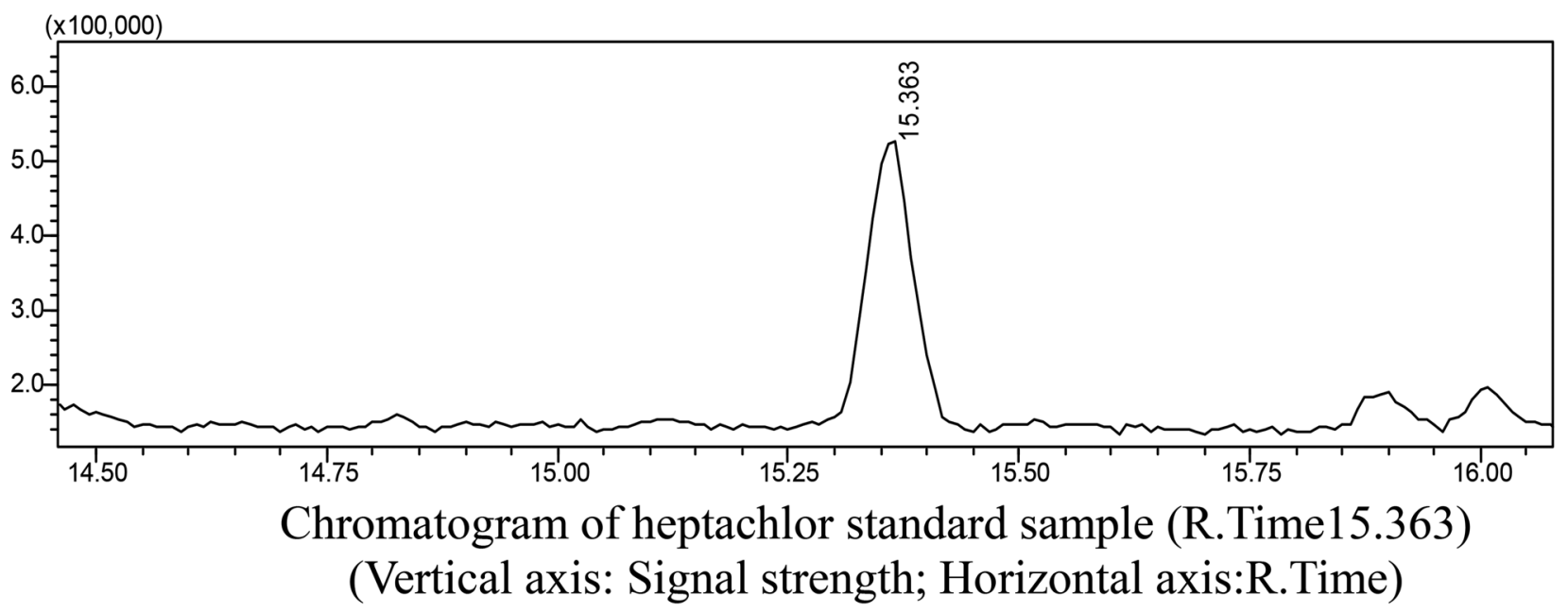

$<$ Target $>>$

Line\#:1 R.Time:15.363(Scan\#:1485) MassPeaks:152

RawMode:Averaged 15.250-15.467(1471-1497) BasePeak:100.00(7742)

BG Mode:Averaged 15.408-15.450(1490-1495)

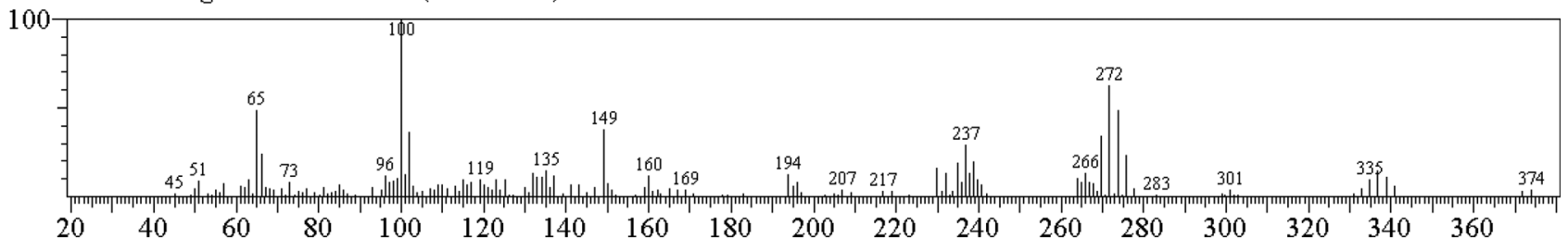

Hit\#:1 Entry:135078 Library:NIST05.LIB

SI:85 Formula:C10H5C17 CAS:76-44-8 MolWeight:370 RetIndex:1857

CompName:Heptachlor \$ 4,7-Methano-1H-indene, 1,4,5,6,7,8,8-heptachloro-3a,4,7,7a-tetrahydro- $\$ \$ 4,7$-Methanoindene, 1,4,5,6,7,8,8

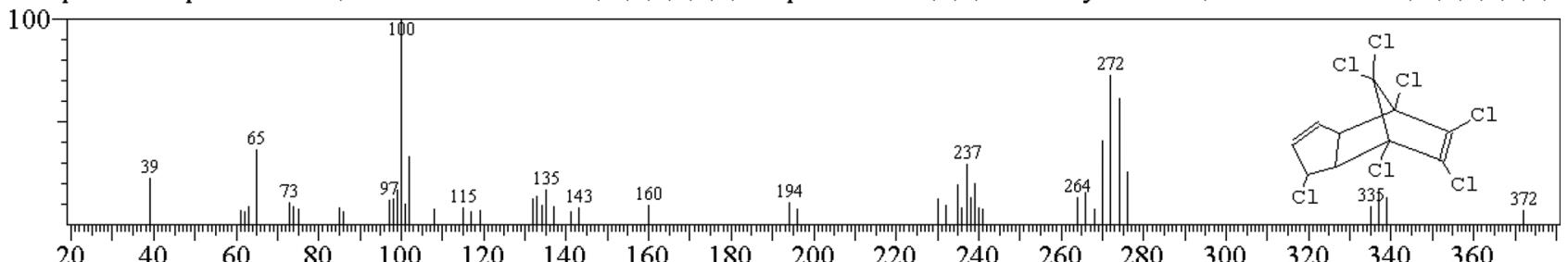

Mass spectra of heptachlor standard sample (Vertical axis:Relative abundance; Horizontal axis: $\mathrm{m} / \mathrm{z}$ )

Fig. 9 Chromatogram and mass spectra of heptachlor standard sample.

the extracts from the culture medium. Through GC-MS analysis, search matching with the NIST spectral library, and comparison with standard compounds and document data, ${ }^{2}$ the metabolites were identified respectively as 1-hydroxychlordene (R. time $18.869 \mathrm{~min}$ ), chlordene epoxide (R. time $20.987 \mathrm{~min}$ ) and heptachlor epoxide (R. time $22.888 \mathrm{~min}$ ), as shown Fig. 9 and 10. Compared to other trace metabolites, the concentration of 1hydroxychlordene and heptachlor epoxy detected was relatively high, i.e. $54.2 \mu \mathrm{g} \mathrm{L}^{-1}$ and $66.6 \mu \mathrm{g} \mathrm{L} \mathrm{L}^{-1}$, which was equivalent to $18.1 \%$ and $22.2 \%$ of the total added concentration of heptachlor respectively.

In previous studies, soil microorganisms transform heptachlor by epoxidation, hydrolysis, and reduction. ${ }^{21}$ When the compound was incubated with a mixed culture of organisms, chlordene (hexachlorocyclopentadiene, its precursor) formed, which was further metabolized to chlordene epoxide. Or heptachlor was first hydrolyzed and then dehydrated to form a heptachlor epoxide. Other metabolites include 1-hydroxychlordene, 1-hydroxy-2,3-epoxychlordene. Soil microorganisms hydrolyze heptachlor to give ketochlordene. ${ }^{22}$ Rats metabolize heptachlor to the epoxide 1-exo-1-hydroxyheptachlor epoxide and 1,2-dihydroxydihydrochlordene. When heptachlor epoxide was incubated with microsomal preparations from liver of pigs and from houseflies, the products found were diol and 1hydroxy-2,3-epoxychlordene. ${ }^{23}$ Metabolic scheme in rats shows two pathways with the same metabolite. The first involves the 


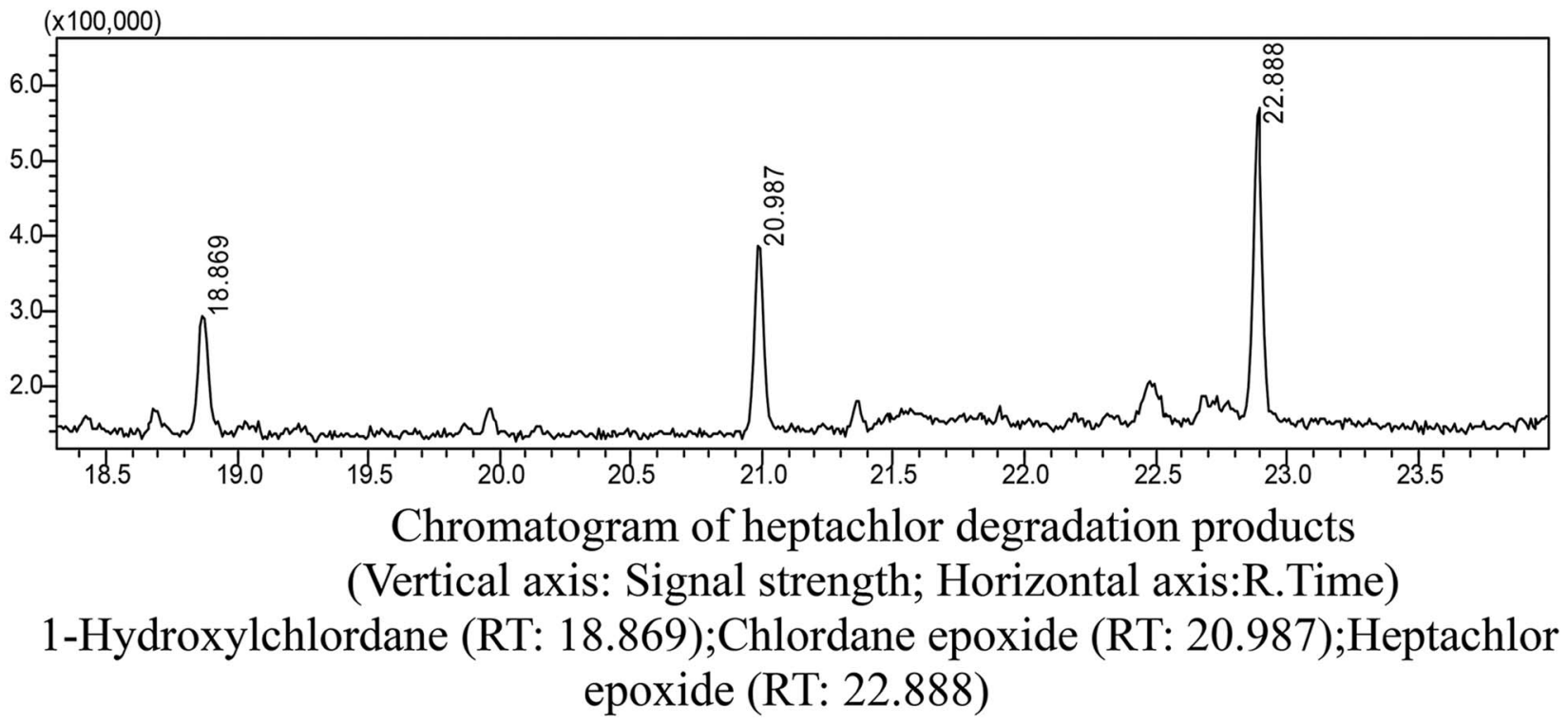

\section{Mass spectra of1-hydroxylchlordene}

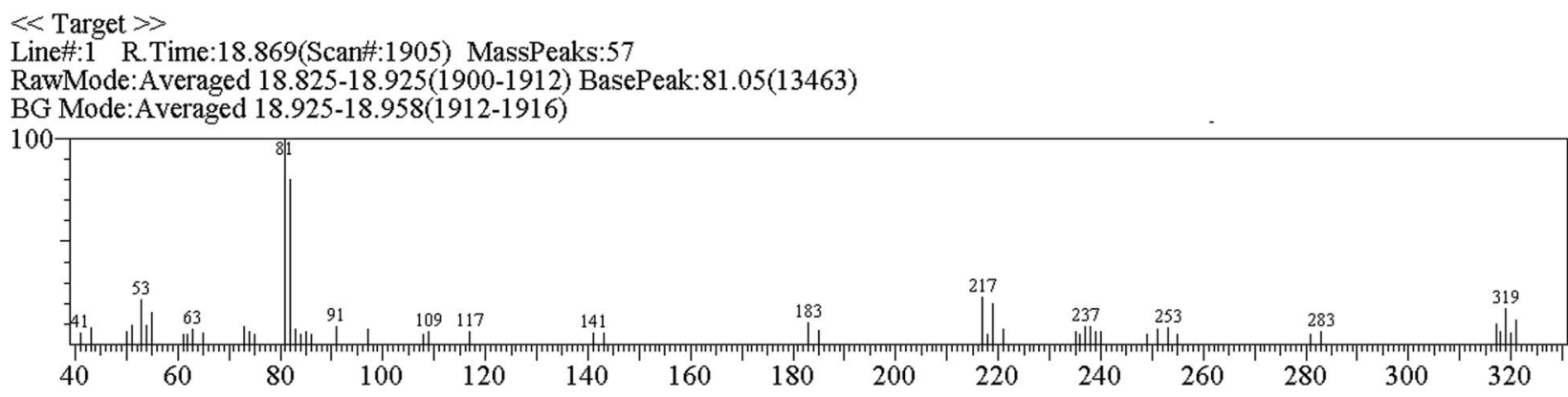

Hit\#:1 Entry:127725 Library:NIST05.LIB

SI:97Formula:C10H6C16O CAS:2597-11-7 MolWeight:352 RetIndex:1879

CompName:1-Hydroxychlordene \$ 4,7-Methano-1H-inden-1-ol, 4,5,6,7,8,8-hexachloro-3a,4,7,7a-tetrahydro- \$\$ 4,7-Methanoinden-1-0

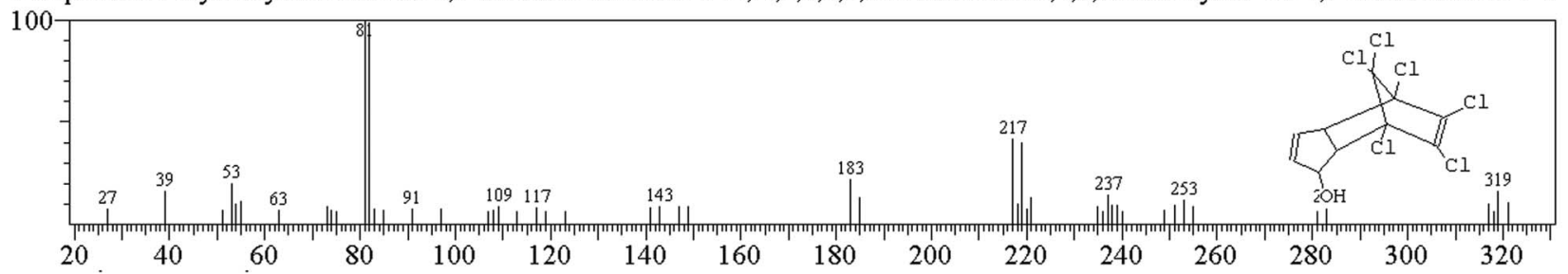

Fig. 10 Chromatogram and mass spectra of heptachlor degradation products.

following scheme: heptachlor $\Rightarrow$ heptachlor epoxide $\Rightarrow$ dehydrogenated derivative of 1-exo-hydroxy-2,3-exo-epoxychlordene $\Rightarrow$ 1,2-dihydrooxydihydrochlordene. The second involves: heptachlor $\Rightarrow$ 1-exo-hydroxychlordene $\Rightarrow$ 1-exo-hydroxy, 2,3exo-epoxychlordene $\Rightarrow$ 1,2-dihydrooxydihydrochlordene. ${ }^{24}$

However, in this study, 1-hydroxy-2,3-epoxychlordene and 1,2-dihydroxydihydrochlordene were not detected. This may be due to the instability of the products of heptachlor epoxide hydrolysis, which could be rapidly converted into other trace metabolites, or the presence of chlorine atoms on the $\mathrm{C} 2$ position of heptachlor epoxide, which affected the hydrolysis of the oxygen ring.

It can also be seen from Fig. 7 that the concentration of 1hydroxychlordene and heptachlor epoxide also gradually decreased over time. When the degradation reaction time reached $180 \mathrm{~h}$, the concentration of 1-hydroxychlordene and heptachlor epoxide decreased to about $8.3 \mu \mathrm{g} \mathrm{L}^{-1}$ and $17.2 \mu \mathrm{g}$ $\mathrm{L}^{-1}$, respectively. This may be due to the enzymatic activity of microorganisms, resulting in metabolites of heptachlor being further degraded. Enzymes are the proteins synthesized by living cells and act as efficient catalysts for their specific substrates. They are biological catalysts for most reactions in the organism. Microorganism could secrete and produce intracellular enzymes such as monooxygenase, and extracellular enzymes such as peroxidase. ${ }^{25}$ Under the catalysis of these enzymes, organic chlorine pollutants could be degraded effectively through multiple pathways. According to the analysis results of heptachlor metabolites, we concluded 


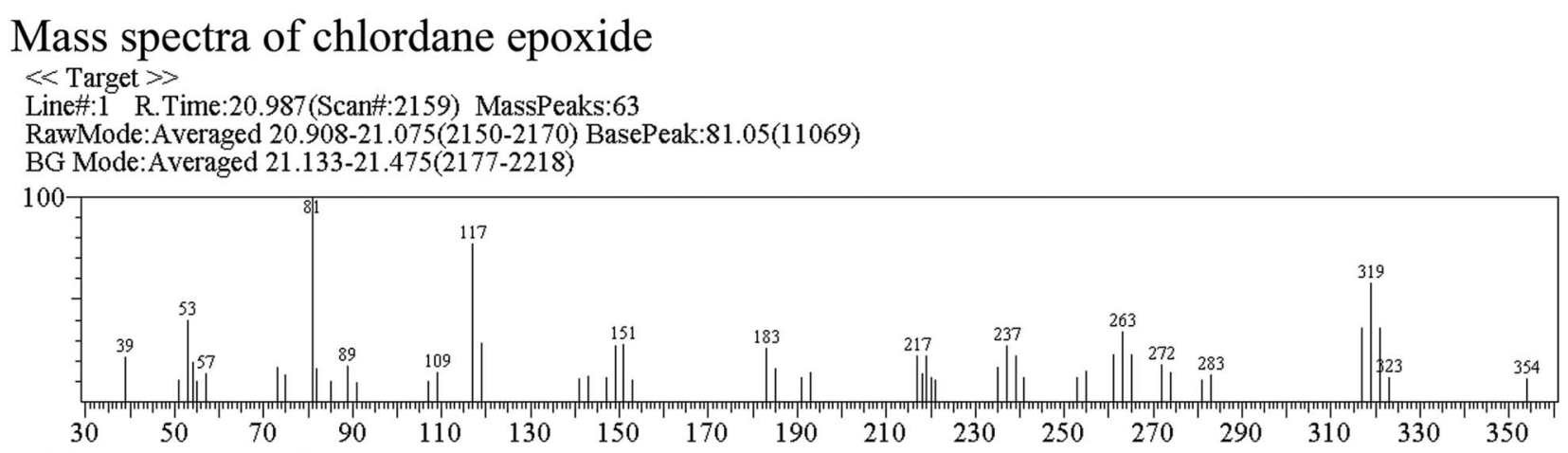

Hit\#:2 Entry:127726 Library:NIST05.LIB

SI:85Formula:C10H6Cl6O CAS:6058-23-7 MolWeight:352 RetIndex:1720

CompName:4, 7-Methanoindan, 3a,4,7,7a-tetrahydro-1,2-epoxy-4,5,6,7,8,8-hexachloro- $\$ \$$ Chlordene epoxide $\$ \$ 2,5$-Methano-2H-inder

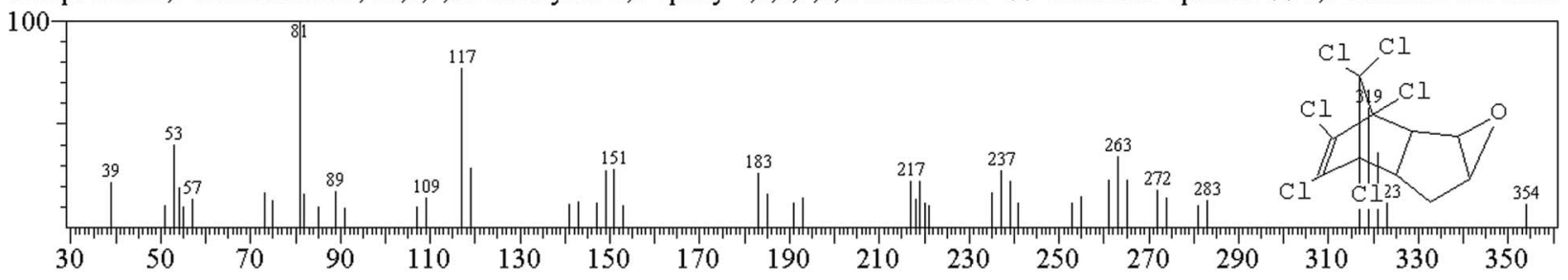

\section{Mass spectra of heptachlor epoxide}

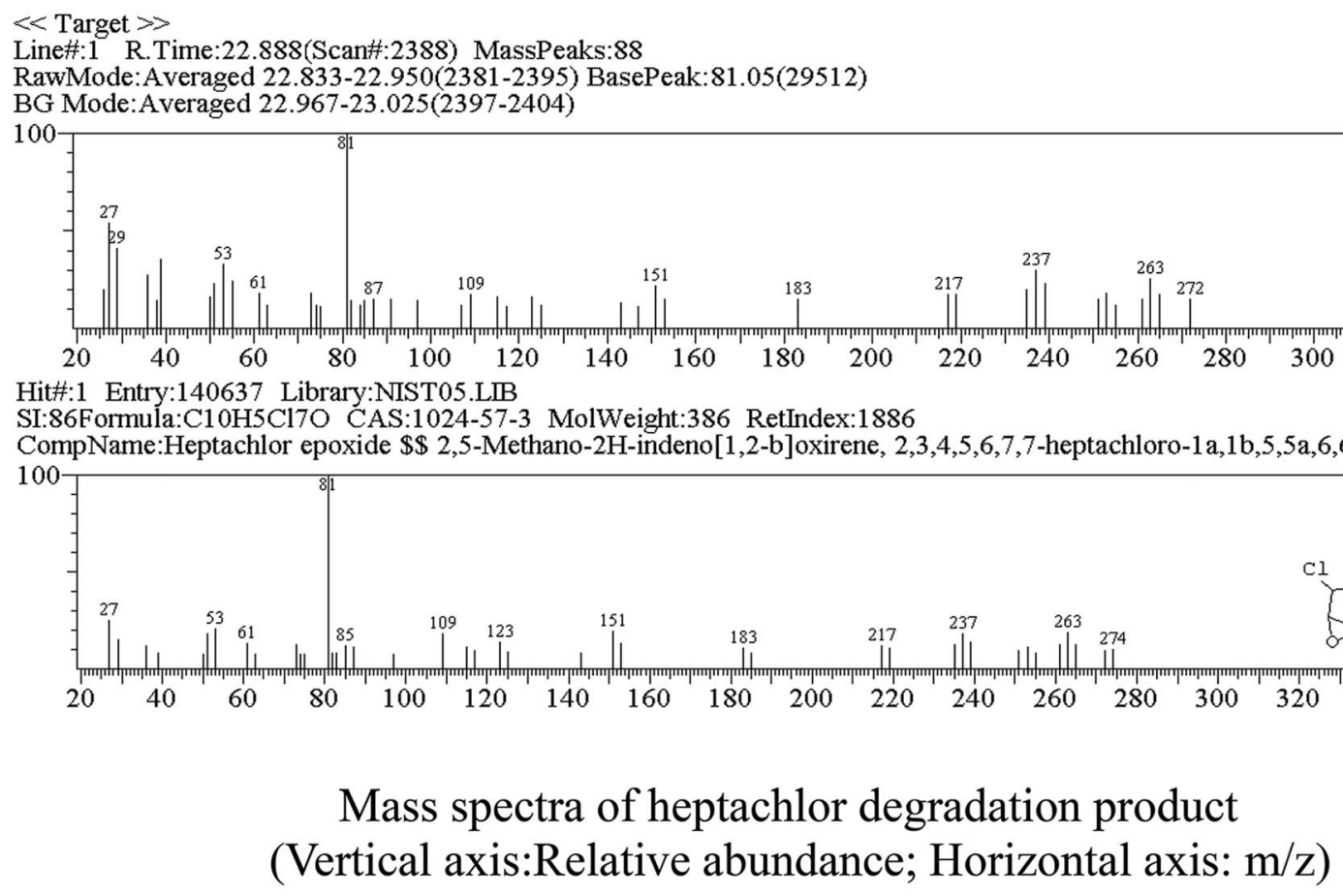

Fig. 10 (contd).

that the degradation and transformation of heptachlor depends on the microbial degradation properties of stain $\mathrm{H}$.

The quantitative analysis of the above heptachlor metabolites shows that strain $\mathrm{H}$ also has certain degradation and conversion ability for 1-hydroxychlordene and heptachlor epoxide. This may be due to the further hydroxylation and substitution of 1-hydroxychlordene to produce multiple hydroxylation products, ${ }^{26}$ and the oxygen ring structure of heptachlor epoxide can be opened by hydrolysis reaction. ${ }^{27}$ Therefore, heptachlor and its metabolites were converted into further less-toxic small molecular metabolites through a series 


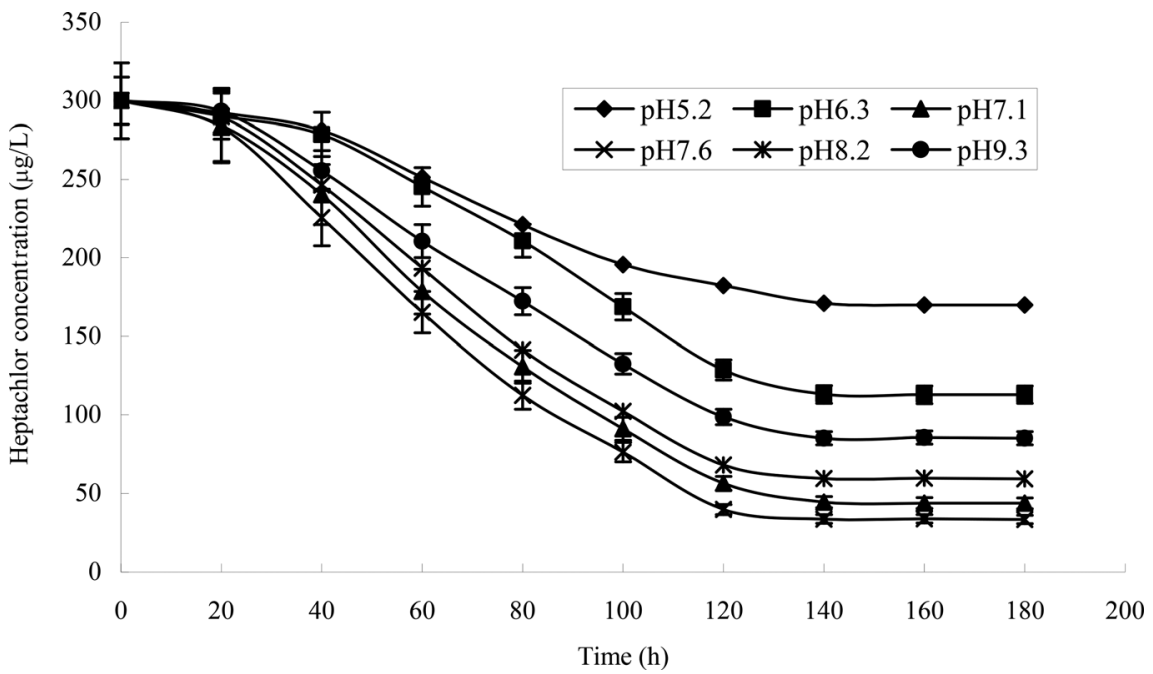

Fig. 11 Degradation curves at different $\mathrm{pH}$ levels.

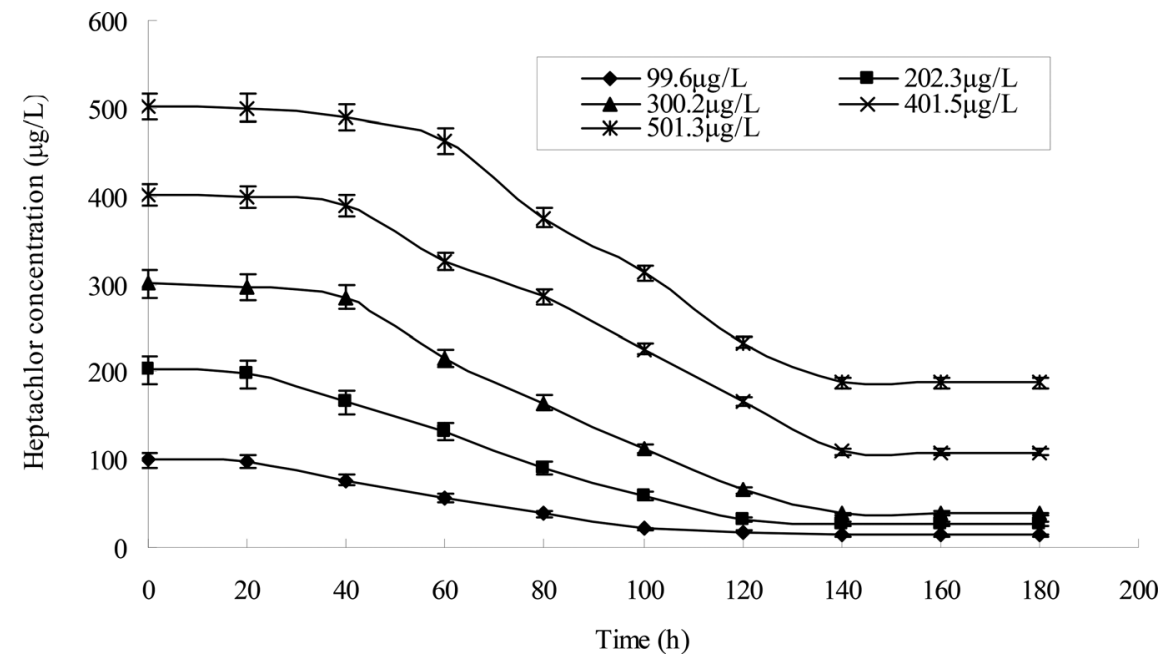

Fig. 12 Degradation curves at different heptachlor initial concentrations.

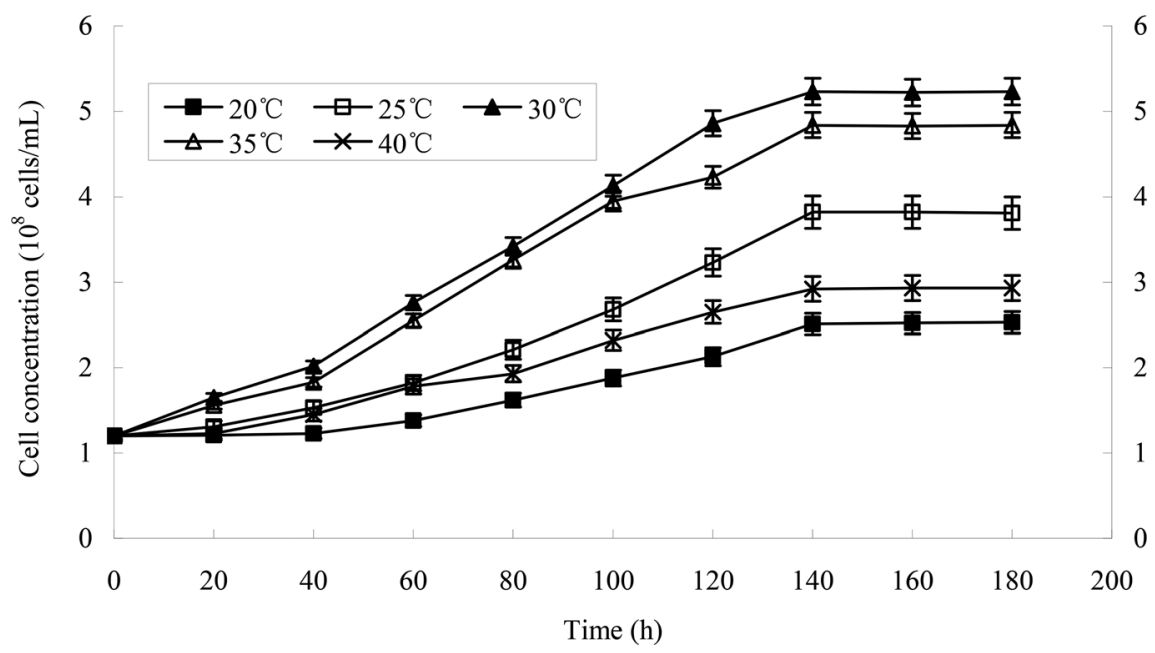

Fig. 13 The growth curves of strain $\mathrm{H}$ at different temperatures. 


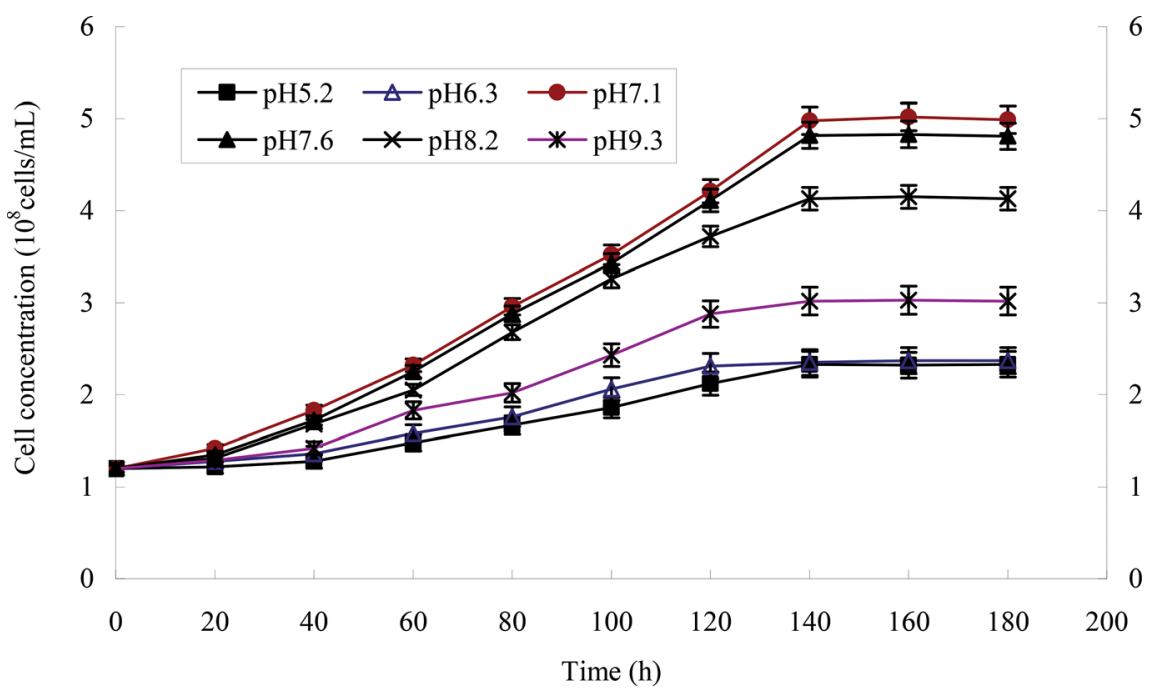

Time (h)

Fig. 14 The growth curves of strain $\mathrm{H}$ at different $\mathrm{pH}$ levels.

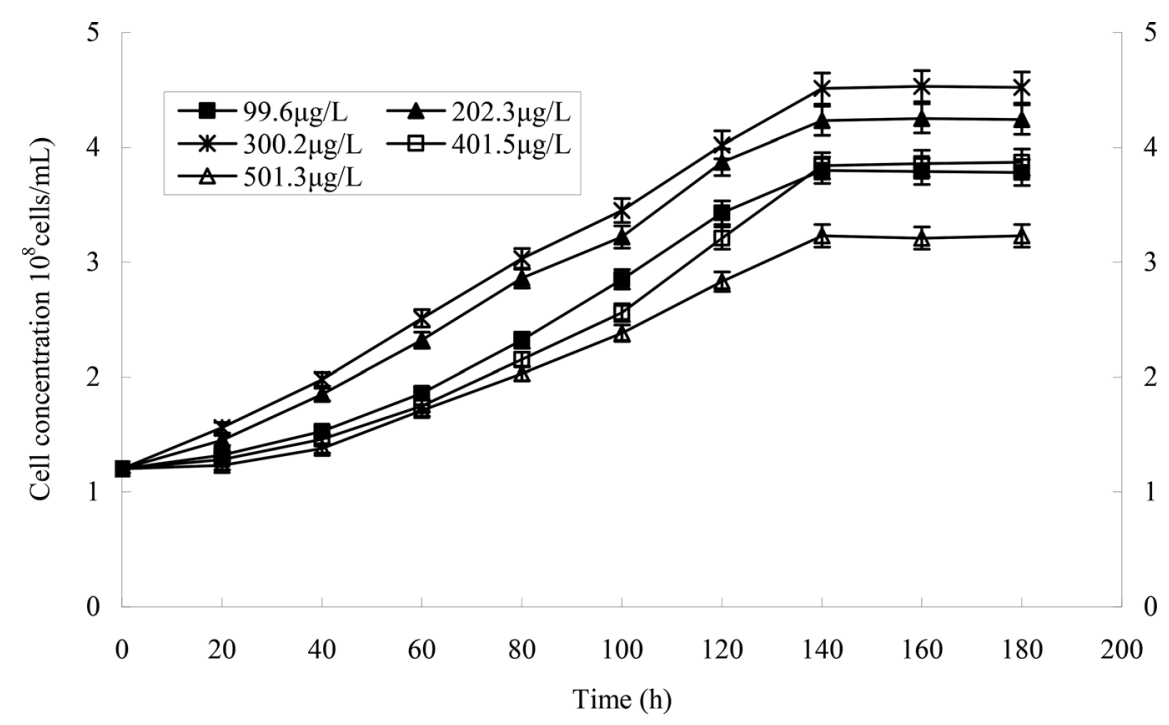

Fig. 15 The growth curves of strain $\mathrm{H}$ at different heptachlor concentrations.

of reactions such as hydroxylation, epoxidation and dechlorination.

Based on the above analysis, we suggest that strain $\mathrm{H}$ has the potential for the remediation of heptachlor-contaminated soil and water at the temperature of $30 \pm 0.5^{\circ} \mathrm{C}$.

Proposed metabolic pathways of heptachlor degradation by strain $\mathrm{H}$ is presented in Fig. 8. We propose the following two initial metabolic pathways of heptachlor by strain $\mathrm{H}$. Pathway (1) hydroxylation at the $\mathrm{C} 1$ position of heptachlor to 1-hydroxychlordene followed by epoxidation and dechlorination to chlordene epoxide; and pathway (2) epoxidation at the C2, C3 positions of heptachlor to heptachlor epoxide, and then heptachlor epoxide was further converted by hydrolysis or dechlorination reaction. On the one hand, dechlorination reaction at the $\mathrm{C} 1$ position of heptachlor epoxide may be transformed into chlordene epoxide. On the other hand, hydrolysis reaction at the $\mathrm{C} 2, \mathrm{C} 3$ position of heptachlor epoxide may be degraded into heptachlor diol. ${ }^{28}$

\section{Conclusions}

In this study, we isolated and screened a heptachlor-degrading microorganism named strain $\mathrm{H}$, which was able to effectively degrade heptachlor at the temperature of $30 \pm 0.5^{\circ} \mathrm{C}$. Experiments showed that strain $\mathrm{H}$ can grow using heptachlor and its degradation products as its carbon source. Strain $\mathrm{H}$ was identified as a novel Gram-negative, short rod-shaped, single-cell bacterial strain. When heptachlor degradation rate reached the maximum, $88.2 \%$ at $130 \mathrm{~h}$, identification of the heptachlor metabolites by GC/MS showed that the main degradation products were 1-hydroxychlordene, heptachlor epoxide and chlordene epoxide. The bioconversion mechanisms of 
heptachlor was accomplished by hydroxylation, epoxidation, and dechlorination at the $\mathrm{C} 1$ position, as well as epoxidation, hydrolysis or dechlorination reaction at the $\mathrm{C} 2$, C3 positions. With the degradation time prolonged, heptachlor and its metabolites could be further converted into less-toxic small molecular metabolites. Thus, strain $\mathrm{H}$ has the potential for the remediation of heptachlor-contaminated soil and water.

\section{Conflicts of interest}

There are no conflicts to declare.

\section{Acknowledgements}

The authors thank the Natural Science Foundation of Shaanxi province, China (No. 2017JM4025) for their financial support.

\section{References}

1 L. Robert, Metcalf "Insect Control", in Ullmann's Encyclopedia of Industrial Chemistry, Wiley-VCH, Weinheim, 2002.

2 A. G. Smith, Chlorinated Hydrocarbon Insecticides, in Handbook of Pesticide Toxicology, ed. Hayes W. J. Jr and Laws E. R. Jr, Academic Press Inc., New York, NY, 1991, pp. 6-3.

3 P. F. Xiao, M. Toshio, I. Kamei and R. Kondo, Metabolism of organochlorine pesticide heptachlor and its metabolite heptachlor epoxide by white rot fungi, belonging to genus Phlebia, FEMS Microbiol. Lett., 2011, 314, 140-146.

4 U.S. Environmental Protection Agency, Guidance for the Reregistration of Pesticide Products Containing Chlorobenzilate as the Active Ingredient, Washington, DC, 1983, pp. 6-7.

5 J. R. W. Miles, C. M. Tu and C. R. Harris, Degradation of heptachlor epoxide and heptachlor by a mixed culture of soil microorganisms, J. Econ. Entomol., 1971, 64(4), 839-841.

6 J. R. W. Miles, C. M. Tu and C. R. Harris, Metabolism of heptachlor and its degradation products by soil microorganisms, J. Econ. Entomol., 1969, 62(6), 1334-1338.

7 E. O. Nwachukwu and J. O. Osuji, Bioremedial degradation of some herbicides by indigenous white rot fungus, Lentinus subnudus, J. Plant Sci., 2007, 2(6), 619-624.

8 Bergey's manual of determinative bacteriology, ed. R. E. Buchanan and N. E. Gibbons, Williams \& Wilkins Company, Baltimore, 1974.

9 X. Z. Dong and M. Y. Cai, Manual of common bacterial system identification, Science Press, Beijing, China, 2001.

10 R. Devereux and S. G. Willis, Molecular microbial ecology manual, Kluwer Academic Publishers, Dordrecht, Netherlands, 1995, pp. 3-11.

11 J. Sambrook and D. W. Russell, Molecular Cloning: A Laboratory Manual, Cold Spring Harbor Laboratory Press, 3rd edn, New York, 2001.

12 A. D. Eaton, L. S. Clesceri, A. E. Greenberg and M. A. H. Franson, Standard Methods for the Examination of
Water and Wastewater, American Public Health Association, Washington, DC, 1998.

13 F. Z. Liu and J. Q. Ma, Practical manual monitoring analysis of soil, Chemical industry press, Beijing, China, 2012, pp. 486489.

14 P. Shen, X. R. Fan and G. W. Li, Microbiological Experiment, Higher Education Press, Beijing, China, 1999.

15 Q. Y. Zhou and S. F. Wang, Microbiology of Environmental Engineering, Higher Education Press, Beijing, 2011, pp. 100-101.

16 Y. W. Qin, L. Zhang, B. H. Zheng and W. Cao, Distribution Characteristics and Sources of OCPs in Estuary Sediments of Main Runoff Flowed into Bohai Bay, J. Agro-Environ. Sci., 2010, 29(10), 1900-1906.

17 L. Guttman and J. V. Rijn, Isolation of bacteria capable of growth with 2-methylisoborneol and Geosmin as the sole carbon and energy sources, Appl. Environ. Microbiol., 2012, 78(2), 363-370.

18 P. F. Xiao and R. Y. Kondo, Degradation of heptachlor by a wood-rot fungus and its enzyme, Chin. J. Environ. Eng., 2013, 7, 3683-3688.

19 J. R. W. Miles, C. M. Tu and C. R. Harris, Degradation of heptachlor epoxide and heptachlor by a mixed culture of soil microorganisms, J. Econ. Entomol., 1971, 64, 839-841.

$20 \mathrm{P}$. F. Xiao and R. Kondo, Biotransformation of 1Hydroxychlordene by White Rot Fungus and Detection of Metabolites, Adv. Mater. Res., 2012, 610-613, 60-63.

21 J. R. Miles, C. M. Tu and C. R. Harris, Metabolism of heptachlor and its degradation products by soil microorganism, J. Econ. Entomol., 1969, 62(6), 1334.

22 M. Feroz, A. A. Podowski and M. A. Q. Khan, Oxidative dehydrochlorination of heptachlor by Daphnia magna, Pestic. Biochem. Physiol., 1990, 36(2), 101-105.

23 J. R. Plimmer, N. N. Ragsdale and D. Gammon, The Encyclopedia of Agrochemicals, John Wiley \& Sons, New York, 2003, vol. 3.

24 California Environmental Protection Agency, Public Health Goal for Heptachlor and Heptachlor Epoxide In Drinking Water - Office of Environment Health Hazard Assessment, California Environmental Protection Agency, 1999.

25 F. Matsuzaki and H. Wariishi, Functional diversity of cytochrome P450s of the white-rot fungus Phanerochaete chrysosporium, Biochem. Biophys. Res. Commun., 2004, 324, 387-393.

26 P. F. Xiao and R. Y. Kondo, Enzymatic degradation of organochlorine insecticide chlordane by white rot fungus, Chinese Agricultural Science Bulletin, 2013, 29(9), 178-183.

27 P. F. Xiao, G. L. Cheng, Y. Z. Song, S. Q. Zhao, S. Ying, Y. F. Li and R. Y. Kondo, Biodegradation of chlordane by white-rot fungi and its metabolic pathway, China Environ. Sci., 2011, 31, 39-45.

28 A. S. Purnomo, S. R. Putra, K. Shimizu and R. Y. Kondo, Biodegradation of heptachlor and heptachlor epoxidecontaminated soils by white-rot fungal inocula, Environ. Sci. Pollut. Res., 2014, 21, 11305-11312. 